\title{
THE EFFECT OF KNOWLEDGE SHARING ON AUDITOR INNOVATION ABILITY USING WORK ETHICS AS MODERATING VARIABLE
}

\author{
Magnaz Lestira Oktaroza ${ }^{1}$, Aria Bayu Pamgestu ${ }^{2}$ \\ ${ }^{1}$ Universitas Islam Bandung \\ ${ }^{2}$ Institut Teknologi Bandung
}

\begin{abstract}
This study aims to determine the effect of knowledge sharing on auditor innovation capabilities that are moderated by work ethic. This research was conducted at the Public Accountant Firm in the city of Bandung. Respondents in this study were external auditors. The research method used is research verification survey with a quantitative approach. Sampling was determined by nonprobability sampling technique with a type of purposive sampling, with a sample of 34 respondents. The data analysis technique used is moderate regression analysis.. The results of the tests that have been done show that knowledge sharing has a significant effect on the auditor's innovation ability. Other test results show that work ethic does not have a significant effect on the ability of innovation and work ethic not to moderate the effect of knowledge sharing on the auditor's innovation ability. Based on these studies, auditors who have high innovation capabilities will be able to provide new ideas that can benefit clients. But in making innovations auditors must remain on track, not violate boundaries, and not violate existing rules. It is expected that this research can provide knowledge to auditors to be able to improve their abilities, especially in the audit field so they can maximize their duties as auditors.
\end{abstract}

KEYWORDS : auditor innovation capabilities, knowledge sharing, work ethics

\section{INTRODUCTION}

The development of science and technology from time to time and the innovations produced by humans are increasingly developing. This phenomenon has an impact on the problems and needs of human life which every day is increasing as well as the auditor.In order to remain able to adjust to the development of science and technology, auditors must always update their knowledge and improve capabilities, and be open in collaborating with various parties, one of which is the participation of auditors in participating in various conferences, seminars, and discussions both at national and international levels. The Indonesian Internal Auditor Institute (IIA Indonesia), on October 10 and 112017 held a National Conference which presented famous speakers from various countries held in Bandung. The participation of auditors in the scientific activities mentioned above is expected to be able to create a strength for auditor professionals in order to remain relevant to the times through a series of knowledge sharing activities This is supported by research conducted by Hilmi Aulawi, et al (2009) which proves that through sharing forums or events has encouraged the growth of knowledge sharing activities within an organization.For individuals in the organization, knowledge sharing is done by discussing with colleagues to find more optimal solutions and more efficient in doing work. For organizations, knowledge sharing is an activity that is used to organize and share useful knowledge and experiences for others in the organization. 
Knowledge needs to be shared with all members of the organization so that knowledge can be used to achieve organizational goals (Nonaka \& Takeuchi, 1995). The value of organizational knowledge of each individual will increase when the knowledge he has is shared (Styhre, 2002).

Auditors as individuals and the Public Accountant Firm as an organization really need an effective and efficient knowledge sharing activity. Auditors as individuals, with the existence of effective and efficient knowledge sharing activities will get optimal information and knowledge in doing their work so that they can improve their ability to innovate in work in accordance with the development of science and technology (Lin, 2007). Increasing the ability of individual innovation in this case the auditor in doing his work will improve the quality of the organization in this case the Public Accounting Firm in achieving its objectives in accordance with the development of science and technology.

Effective and efficient knowledge sharing can improve an innovation for auditors in the Public Accountant Firm, if in carrying out their work the auditor is accompanied by a high work ethic that is having attitude, personality, character, behavior and ethics that will determine the feasibility of doing work. Internal feasibility that will determine a person's ability to work (Khasanah, 2014, p. 9).

\section{LITERATURE REVIEW}

\section{The Effect of Knowledge Sharing on Auditor Innovation Ability}

Management of knowledge resources can be carried out effectively if employees have the desire to work with their colleagues to participate ( Lin ,2007). Organizations that are able to encourage their employees to contribute to the knowledge they have into groups or organizations will provide a great opportunity to improve the ability of their employees to create new ideas and provide opportunities in developing innovation capabilities (Darroch and McNaughton, 2002 in Aulawi et al. 2009).

The results of previous studies conducted by Novian Setyaji Saputro and Yuniadi Mayowan (2018: 11) show that employees of the Rumah Opa kitchen and lounge have successfully applied knowledge sharing in terms of experience and personal knowledge held by employees within the company.

Personal knowledge and experience helps employees improve their ability to create new methods or ways of working and improve work processes to be more effective and efficient. The results of this study indicate that knowledge sharing variables have a direct influence on individual innovation capability.

H1: Knowledge Sharing affects the Auditor Innovation Ability.

\section{The Effect of Work Ethics on Auditor Innovation Ability}

The individual and organizational innovation capabilities are the main requirements for every organization to survive in a very fast and dynamic environment. (Calantone et al., 2002; Terziovski, 2007). In addition, Abbasi et al. (2012) states that work ethic is very necessary as an organizational culture and values in organizations that can help organizations to get better results by using the human resources owned by the organization. The work ethic of the leaders of the organization in carrying out its activities is an example for employees in encouraging 
them to innovate, trust and loyalty to relationships between employees in carrying out the tasks of the organization.

The results of previous studies indicate a relationship between work ethic and innovation ability in the organization as stated in the results of research conducted by Cloud and Akram (2012) that the ability of innovation is significantly and positively influenced by work ethic. In addition, Muhammad Farrukh, Sonia Butt, and Shaheen Mansori (2015: 129) in their research showed that there is a positive and significant relationship between work ethic and innovation ability.

H2: Work Ethics influences Auditor Innovation Ability

\section{Work Ethics Moderating the Effects of Knowledge Sharing on Auditor Innovation Ability}

Work ethic is the values of a person who encourages someone to do knowledge sharing so that it works not only because of personal interests but also for the benefit of the people. Work ethic applies in various aspects, including knowledge sharing (Porter, 2010). Therefore, the values of work ethics have an important role in developing knowledge and innovation for employees and organizations to be able to survive.Previous research conducted by (Kumar and Rose, 2012) proves that work ethic has a significant influence in moderating the influence of knowledge sharing with the ability of innovation. The results of the study stated that innovation is highly dependent on the knowledge sharing capabilities of employees while knowledge sharing is not a natural behavior that is owned by individuals but that behavior can be cultivated.In line with the above research, the research conducted by Raswita Nengsih (2016: 80) states that work ethics can be a moderating variable between knowledge sharing and the auditor's innovation ability in public accountants.

H3: Work Ethics moderates the Effects of Knowledge Sharing on Auditor Innovation Ability

Based on the above framework, the research model of the impact of the work ethic in moderating the effect of knowledge sharing on auditor innovation ability can be described as follows:

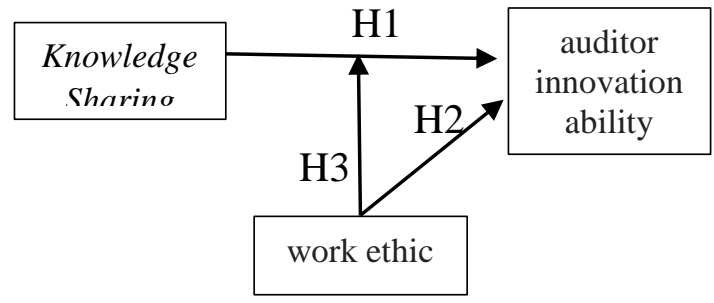

Figure 1 : Research Model

\section{RESEARCH METHODOLOGY}

The research method used in this study is a descriptive method with verification and a quantitative approach

\section{Samples}

The sample of this research is 34 auditors in Public Accounting Firm on Bandung City representative by using purposive sampling result technique. Data collection is done using 
a questionnaire consisting of: 17 statement for nowledge sharing; 17 statements for Innovation Ability Auditor; 24 item statements for Work Ethics.

B. Data Analysis

Test of validity instrument using the Pearson Product Moment with the provisions as follows: If $r \geq 0,3$ then the statement items from the questionnaire are valid.

If $\mathrm{r}<0,3$, the statement items from the questionnaire are not valid.

Reliability Test uses Cronbach Alpha formula with provisions as follow: if the value alpha> 0.60 , then statement items from questionnaire are reliable.

Hypothesis testing is done by using Moderated Regression Analysis (MRA)

\section{RESULTS OF HYPOTHESIS TESTING}

\section{Validity Analysis:}

The results of testing the validity of the knowledge sharing questionnaire items, auditor innovation ability, and work ethic are valid. The results of the test are shown as follow:

Table 1: Validity Test Result

\begin{tabular}{|l|l|}
\hline Variable Name & Result \\
\hline Knowledge Sharing & Valid \\
\hline $\begin{array}{l}\text { Auditor Innovation } \\
\text { Ability }\end{array}$ & Valid \\
\hline Work Ethic & Valid \\
\hline
\end{tabular}

\section{Reliability Analysis:}

Test results Reliability item knowledge sharing questionnaire, auditors innovation ability, and work ethic are reliable. The results of the test are shown as follow:

Table 2: Reliability Test Result

\begin{tabular}{|l|l|l|l|}
\hline Variable & Items & $\begin{array}{l}\text { Cronbach's } \\
\text { Alpha }\end{array}$ & Result \\
\hline Knowledge Sharing & 17 & 0,913 & Reliable \\
\hline Work Ethic & 24 & 0,857 & Reliable \\
\hline AuditorInnovation Ability & 17 & 0,869 & Reliable \\
\hline
\end{tabular}

\section{Hypothesis testing:}

\section{A. Partial Hypothesis Test}

The following are the results of the partial test (t test) using the SPSS version 23. 2019 program presented in the following: 
Tabel 3: Partial Hypothesis Test

\begin{tabular}{|c|c|c|c|c|c|}
\hline \multicolumn{6}{|l|}{ Coefficients $^{\mathrm{a}}$} \\
\hline \multirow[b]{2}{*}{ Model } & $\begin{array}{l}\text { Unstan } \\
\text { Coeffic }\end{array}$ & $\begin{array}{l}\text { Irdized } \\
\text { nts }\end{array}$ & $\begin{array}{l}\text { Standardized } \\
\text { Coefficients }\end{array}$ & \multirow[b]{2}{*}{$\mathrm{T}$} & \multirow[b]{2}{*}{ Sig. } \\
\hline & B & $\begin{array}{l}\text { Std. } \\
\text { Error }\end{array}$ & Beta & & \\
\hline \begin{tabular}{|l|l|}
1 & (Constant)
\end{tabular} & 24.468 & 9.700 & & 2.523 & .017 \\
\hline $\begin{array}{l}\text { Knowledge } \\
\text { Sharing }\end{array}$ & .521 & .123 & .606 & 4.242 & .000 \\
\hline Work Ethic & .056 & .122 & .065 & .456 & 651 \\
\hline
\end{tabular}

\section{Knowledge Sharing influences the Auditor Innovation Ability}

Based on table 3, it can be seen that the significance probability for the knowledge sharing variable of 0.000 is smaller than the 0.05 level of significance, it can be concluded that variable knowledge sharing has a significant effect on the auditor's innovation ability.

\section{Work Ethic influences the Auditor Innovation Ability}

Based on table 3 it can be seen that the probability of significance for the work ethic variable of 0.651 is greater than the 0.05 level of significance, so it can be concluded that work ethic variables did not affect to the auditor innovation ability.

\section{Moderate Regression Analysis (MRA)}

Following are the test results of the Moderate Regression Analysis using the SPSS version 23. 2019.

\section{Tabel 4: Moderate Regression Analysis}

Coefficients $^{\mathrm{a}}$

\begin{tabular}{|c|c|c|c|c|c|}
\hline \multirow[b]{2}{*}{ Model } & \multicolumn{2}{|c|}{$\begin{array}{l}\text { Unstandardized } \\
\text { Coefficients }\end{array}$} & \multirow{2}{*}{\begin{tabular}{|l|}
$\begin{array}{l}\text { Standardized } \\
\text { Coefficients }\end{array}$ \\
Beta \\
\end{tabular}} & \multirow[b]{2}{*}{$\mathrm{T}$} & \multirow[b]{2}{*}{ Sig. } \\
\hline & B & Std. Error & & & \\
\hline $1 \quad$ (Constant) & 52.489 & 52.980 & & .991 & .330 \\
\hline $\begin{array}{l}\text { Knowledg } \\
\text { e Sharing }\end{array}$ & -.097 & 1.155 & -.113 & -.084 & .933 \\
\hline $\begin{array}{l}\text { Work } \\
\text { Ethic }\end{array}$ & -.342 & .750 & -.400 & -.456 & .651 \\
\hline $\begin{array}{l}\text { Knowledg } \\
\text { e Sharing * } \\
\text { Work } \\
\text { Ethic }\end{array}$ & .009 & .016 & .917 & .538 & .594 \\
\hline
\end{tabular}

a.

Dependent Variable: Auditor Innovation Ability

Based on table 4, it can be seen that the significance probability for thework ethic variable in moderating is 0.594 greater than the 0.05 level of significance, it can be concluded that the work ethic variable does not moderate the effect of knowledge sharing on auditor innovation capabilities 
Print ISSN: 2053-4019(Print), Online ISSN: 2053-4027(Online)

Table 5: Hypothesis Testing Result

\begin{tabular}{|c|c|c|c|c|c|}
\hline \multicolumn{2}{|c|}{ Hypothesis } & Prediction & Result & Significant & Explanation \\
\hline $\begin{array}{l}\mathrm{H} \\
1\end{array}$ & $\begin{array}{l}\text { Knowledge Sharing influences the } \\
\text { Auditor Innovation Ability }\end{array}$ & Influence & $\begin{array}{l}\text { Influenc } \\
\mathrm{e}\end{array}$ & 0.000 & Accepted \\
\hline $\begin{array}{l}\mathrm{H} \\
2\end{array}$ & $\begin{array}{l}\text { Work Ethic influences the Auditor } \\
\text { Innovation Ability }\end{array}$ & Influence & $\begin{array}{l}\text { Not } \\
\text { Influenc } \\
\mathrm{e}\end{array}$ & 0,651 & Rejected \\
\hline $\begin{array}{l}\mathrm{H} \\
3\end{array}$ & $\begin{array}{l}\text { The Work Ethic moderates the } \\
\text { Effects of Knowledge Sharing on } \\
\text { the Auditor Innovation Ability }\end{array}$ & moderate & $\begin{array}{l}\text { Not } \\
\text { Moderat } \\
\mathrm{e}\end{array}$ & 0,594 & Rejected \\
\hline
\end{tabular}

\section{DISCUSSION}

\section{Knowledge Sharing influences the Auditor Innovation Ability}

Based on the results of the partial regression test (t-test) obtained a significance value on the knowledge sharing variable of $0,000<0.05(\alpha)$, this shows that knowledge sharing has a significant effect on the auditor innovation ability. It can be said that knowledge sharing carried out within the Public Accountant Firm has been implemented well. The better the application of knowledge sharing, the more innovative capabilities of auditors will be. These results are supported by factors from top management support, namely the leaders are interested in the importance of the benefits of knowledge sharing and the leadership supports knowledge sharing between coworkers. Another supporting factor is knowledge collecting, that is, coworkers provide the knowledge they have when other coworkers ask and coworkers share information when other coworkers ask.

Knowledge sharing that is done by means of social interaction with other people will be able to improve intellectual quality that is owned so that it can support the ability to innovate. This research is supported by previous research conducted by Kumar and Rose (2012) which states that knowledge sharing has a positive effect on the ability of innovation in organizational employees.

\section{Work Ethic influences the Auditor Innovation Ability}

Based on the results of the partial regression test (t-test) for the hypothesis obtained a significance value on the work ethic variable of $0.651>0.05(\alpha)$, this indicates that there is no significant effect of work ethic on the auditor's innovation ability. This is supported by data stating that the auditors at the Public Accounting Firm studied were still lacking in empathy in giving motivation to coworkers who when experiencing difficulties. This can happen because each auditor has their own level of difficulty so that to provide motivation to others is still very difficult to do.This research is supported by previous research conducted by Raswita Nengsih (2012) which states that the work ethic variable does not significantly influence the innovation ability of public accountants.

\section{The Work Ethic Moderates the Effects of Knowledge Sharing on the Auditor Innovation} Ability

Based on the results of the moderate regression analysis, it is stated that the work ethic does not moderate the effect of knowledge sharing on the auditor's innovation ability because the significance value of 0.594 is greater than the alpha value $\alpha=0.05$. The results of this study 
are supported by data stating that Knowledge sharing is basically a way to share ideas, knowledge, and experiences that individuals have with other individuals.An auditor must continue to renew himself by sharing knowledge about the auditing sciences to support his ability to carry out the audit process. If the auditor knows the new sciences, allows the auditor to be able to do things that he previously could not do so that they can improve their innovation capabilities (Essianda and Hatane, 2016). Work ethic is a natural behavior that arises from within human beings so that the work ethic depends on the willingness or desire in each person, so this shows that the work ethic does not moderate the influence of knowledge sharing on the auditor's innovation ability.

\section{CONCLUSION}

Based on the results of the research described in the previous chapter, conclusions can be drawn as follows:

Knowledge sharing has a significant influence on auditor innovation capabilities meaning that the knowledge sharing carried out in Public Accounting Firm has been well implemented. The better the implementation of knowledge sharing, the more the auditor's innovative ability will be carried out in the Public Accounting Firm, so that the knowledge and capabilities of the organization in the audit field will increase and then be able to apply it well to maximize the services provided and can satisfy the clients.

The work ethic does not have a significant effect on the auditor's innovation ability, meaning that the increase in the auditor's innovation ability does not depend on the work ethic because the auditor's innovation ability lies in the knowledge and skills possessed by an auditor while the work ethic lies in the auditor's attitude or ethics at work. So that there is no significant effect of work ethic on the auditor's innovation ability.

The work ethic does not moderate the influence of knowledge sharing on the auditor's innovation ability because work ethic does not have a significant effect on knowledge sharing and the auditor's innovation ability and work ethic are natural behaviors that arise from within humans so this shows that the work ethic does not moderate the influence of knowledge sharing to the auditor's innovation ability.

\section{REFERENCES}

[1] Ancok, Djamaludin. 2012. Psikologi Kepemimpinan \& Inovasi. Jakarta : Erlangga. Arikunto, Suharsimi. 2005. Manajemen Penelitian, Cetakan ke-7. Jakarta : PT Rineka Cipta

[2] _. 2006. Prosedur Penelitian Suatu Pendekatan Praktek, Edisi Revisi IV. Jakarta : Rineka Cipta.

[3] _. 2006. Metodelogi penelitian. Yogyakarta: Bina Aksara.

[4] _. 2010. Prosedur Penelitian. Jakarta: Renika Cipta.

[5] Aulawi, Hilmi., dkk. 2009. Hubungan Knowledge Sharing Behavior dan Individual Innovation Capability. Jurnal Teknik Industri, Vol. 11, No. 2. Bandung : Institut Teknologi Bandung. Hal : 174-187.

[6] _.2009. Knowledge Sharing Behavior, Antecedent and Their Impact on The Individual Innovation Capability. Journal of Applied Sciences Research, Vol. 5, No. 12. Bandung : Institut Teknologi Bandung. Hal : 2238-2246. 
[7] Damayanti, Urfy. 2009. Kontribusi Motivasi dan Etos Kerja Terhadap Komitmen Profesional serta Dampaknya pada Peningkatan Kinerja Auditor. Skripsi. Jakarta : Universitas Islam Negeri Syarif Hidayatullah.

[8] Essianda, Ivana \& Saarce Elsye Hatane. 2016. Pengaruh Intellectual Capital Terhadap Financial Performance Melalui Innovation Capability Sebagai Intervening Variable Kantor Akuntan Publik di Surabaya. Business Accounting Review, Vol. 4, No. 1. Surabaya : Universitas Kristen Petra. Hal : 481-492.

[9] Farrukh, Muhammad., Sonia Butt \& Shaheen Mansori. 2015. Innovation Capability : The Role of Islamic Work Etchics. Journal of Asian Business Strategy,Vol. 5, No. 7. Hal : 125-131

[10] Firmaiansyah, Danang. 2014. Pengaruh Berbagi Pengetahuan Terhadap Kinerja Karyawan Melalui Inovasi. Jurnal Ilmu Manajemen, Vol. 2, No. 1. Surabaya : Universitas Negeri Surabaya.

[11] Ghozali, Imam. 2001. Aplikasi Analisis Multivariate dengan Program SPSS. Edisi ke1. Semarang : BP UNDIP.

[12] _. 2018. Aplikasi Analisis Multivariate dengan Program IBM SPSS 25. Edisi ke-9. Semarang : Universitas Diponegoro.

[13] Indriasari, Ika. 2013. Pengaruh Komitmen Afektif, Persepsi Saling Ketergantungan Tugas dan Keterlibatan Kerja Terhadap Pengetahuan pada Auditor. Jurnal Dinamika Ekonomi \& Bisnis. Jepara : Universitas Islam Nusantara.

[14] Ingsih, Kusni. 2011. Menerapkan Etos Kerja Profesional dalam Meningkatkan Kinerja. Seminar Nasional Teknologi Informasi \& Komunikasi Terapan. Semarang : Universitas Dian Nuswantoro.

[15] Kuncoro, Mudrajad. 2001. Metode Penelitian Kuantitatif. Yogyakarta : UPP AMP YKPM.

[16] _. 2003. Metode Riset untuk Bisnis dan Ekonomi : Bagaimana meneliti \& menulis tesis?. Jakarta : Erlangga.

[17] Lin, Hsiu-Fen. 2007. Knowledge Sharing and Firm Innovation Capability: An Empirical Study. International Journal of Manpower Vol. 28 No. 3/4. Taiwan : National Taiwan Ocean University. Hal : 315-332

[18] Lovinanda, Stella \& Saarce Elsye Hatane. 2016. Pengaruh Innovation Capability Terhadap Financial Performance melalui Brand Equity Sebagai Variabel Intervening pada Industri Perhotelan di Surabaya. Business Accounting Review, Vol. 4, No.1. Surabaya : Universitas Kristen Petra. Hal : 133-144

[19] Mardlillah, Arina Idzna \& Kusdi Rahardjo. 2017. Pengaruh Knowledge Sharing Terhadap Kompetensi Individu dan Kinerja Karyawan. Jurnal Administrasi Bisnis. Vol. 46 No.2. Malang : Universitas Brawijaya.

[20] Moch. Nazir. 2003. Metode Penelitian. Jakarta : Salemba Empat.

[21] Mulyana, Muchammad Assegaff \& Wasitowati. 2015. Pengaruh Knowledge Donating dan Knowledge Collecting Terhadap Innovation Capability Kasus Pengembangan UKM Batik di Provinsi Jawa Tengah-Indonesia. Jurnal Manajemen Teknologi Vol. 14, No. 3. Semarang : Universitas Islam Sultan Agung. 